\title{
Financial vs. Non-financial Stocks: Time-varying Correlations and Risks
}

\author{
Thomas J. Flavin \\ National University of Ireland Maynooth \\ Eirini Sygelaki ${ }^{1}$
National University of Ireland Maynooth
}

\begin{abstract}
We analyze the time-varying co-movements of both financial and nonfinancial stock returns across countries to analyze the conditional correlation exhibited by cross-country pairs during the recent financial crisis. Using an asymmetric bivariate GARCH model, the analysis is conducted for a number of developed and developing countries. Given the origins of this current crisis, we expect increased correlation between financial sectors. However, recent correlations are not excessively large when compared to those earlier in this decade. Principal components analysis reveals one common driver of these pairwise correlations which may be related to U.S. returns and market liquidity.
\end{abstract}

JEL Classification: G15, G21, C32.

Keywords: Stock co-movements, Asymmetric shocks, Principal components

\section{Introduction}

Asset return co-movements are known to increase during periods of high volatility (see Longin and Solnik, 2001; and Forbes and Rigobon, 2002; among others). Given the financial turmoil of the recent past, we analyze the time-varying correlations of financial stocks across international markets to ascertain if current levels of comovement are large by historical standards. For the past two years, financial markets have been gripped with fear and uncertainty as the most severe crisis experienced since 1929 has unfolded. This crisis has been truly global as it has spread across national borders and affected all markets in the financial system. The rapid downward spiral of many asset markets has led to real economic effects, with many

\footnotetext{
${ }^{1}$ Thomas Flavin is a Senior Lecturer in Finance at the National University of Ireland Maynooth and Eirini Sygelaki is a Ph.D. candidate at the National University of Ireland Maynooth. Corresponding author: Thomas Flavin, Dept. of Economics, Finance \& Accounting, NUI Maynooth, Ireland, Thomas.flavin@nuim.ie
} 
economies sliding into recession. Rising unemployment and falling output is a feature of many economies, further suppressing any anticipated recovery in asset prices. By common consensus, this crisis had its origins in the financial sector, with the initial shock traced to the U.S. sub-prime and associated credit derivative markets. In particular, the rapid growth of securitized financial products in the early part of this decade had created pools of sub-prime assets which were 'rated and tranched' and sold around the globe. This process had been widely applied throughout the financial sector, and due to a high demand for such products, the range of underlying assets expanded and ultimately encompassed sub-prime mortgages. The demand for these assets was fuelled by the offer of large absolute return compared to other assets in what was quite a low interest rate environment. The creators (suppliers) of such products also had a great incentive to participate in this market as the margins charged to sub-prime mortgage holders reaped high returns, and the risks could be 'distributed' throughout the financial system. ${ }^{2}$

However, the fragility of this market was savagely exposed as U.S. property prices began to fall. Mortgage holders found themselves unable to meet re-payments on houses that were starting to experience negative equity. Consequently, defaults began to increase and buyers of tranched credit derivatives suffered losses. Financial institutions were greatly exposed to these risks due to significant cross-holdings of each other's securitized products. Many of those who had issued these securitized products through associated Special Purpose Vehicles (SPV) or conduits were forced to take these assets back on to their balance sheets, with devastating effects on their financial health. A liquidity crisis ensued as institutions began to hoard liquid assets due to uncertainty about their own future needs and fear of counterparty risk due to the pervasive nature of the shock. Debt maturities shortened and spreads increased until liquidity shortages began to impair the operation of many institutions. This crisis was an important factor in spreading the shock across different asset markets as good assets were sold off to help financial institutions raise cash to meet increasing capital requirements and offset their inability to raise capital in markets for shortterm finance, such as asset-backed commercial paper (ABCP). Brunnermeier and Pedersen (2009) present a model of this type of shock transmission, whereby liquidity risk in one market spills over to other markets, creating 'liquidity sprials'.

In this paper, we analyze the cross-country time-varying co-movements of equity returns within two broadly defined sectors, namely financial and non-financial stocks. Our investigation is conducted on a sample of eleven countries over the past decade as we bid to ascertain whether asset return correlations were higher during the current turmoil than previously recorded. We generate time-varying correlations by estimating an asymmetric bivariate GARCH model, whereby the United States serves as a base or 'ground-zero' market and we analyze its co-movement with each of the remaining ten markets. The motivation for employing an asymmetric model stems from Cappiello, Engle and Sheppard (2006) who find significant asymmetries

\footnotetext{
${ }^{2}$ For an excellent review of the recent crisis, see Brunnermeier (2009).
} 
in conditional correlations, with a stronger reaction in stocks than bonds to common bad news events. Our results reveal a number of interesting facts. Firstly, while correlations between international financial sectors have increased over the period of the recent financial turmoil, current levels of co-movement are not excessive by historical standards. Secondly, the time variation inherent in the correlation of each country with the U.S. exhibits a great deal of commonality across markets, and one common factor accounts for almost all of the variation. Thirdly, the results from our analysis of the financial sector also pertain to the non-financial sector. This implies that the two sectors are inextricably linked and shocks to the financial sector are largely systematic.

The paper is organized as follows: Section 2 reviews our econometric methodology and describes the data employed in our study. Section 3 reports our empirical findings for the financial sector stocks. Section 4 extends our methodology to non-financial stocks and highlights the key differences and similarities between these two sectors. Section 5 contains our concluding remarks.

\section{Methodology and Data}

\subsection{Econometric Model}

Our goal is to analyze the co-movements of both financial and non-financial stocks across countries over the past decade. Given the stylized features associated with asset returns such as volatility clustering and fat tails, we adopt a model from the (G)ARCH family of Engle (1982) and Bollerslev (1986). In particular, we employ a bivariate GARCH model to extract these time-varying conditional correlations of stock returns across different pairs of countries and sectors. This approach simultaneously models both the conditional mean and conditional second-order moments of the asset return process. The dynamics of the former are captured through a vector autoregression (VAR) model with an additional factor to capture the potential asymmetric response of returns to negative shocks. Given the volume of literature documenting time-variation in the covariance matrix of asset returns, we employ a bivariate GARCH $(1,1)$, augmented in a fashion similar to Glosten, Jagannathan and Runkle (1993) to account for asymmetric responses to positive and negative shocks. The rationale for this approach is that the error terms can be interpreted as a measure of news (Engle and $\mathrm{Ng}$; 1993, among others), with an unexpected increase (decrease) in stock returns indicating the arrival of good (bad) news. We ensure that conditional variances are strictly positive by employing the BEKK parameterization. Specifically, our model can be represented as follows:

$$
\begin{aligned}
& R_{t}=\Omega+\Phi R_{t-1}+\varepsilon_{t}+\theta \eta_{t-1} \\
& \varepsilon_{t} \sim N\left(0, H_{t}\right) \\
& H_{t}=C^{\prime} C+A\left(\varepsilon_{t-1} \varepsilon_{t-1}^{\prime}\right) A^{\prime}+B H_{t-1} B^{\prime}+\Gamma\left(\eta_{t-1} \eta_{t-1}^{\prime}\right) \Gamma^{\prime}
\end{aligned}
$$

where $\mathrm{R}_{\mathrm{t}}=\left(\mathrm{r}_{\mathrm{us}, t}, \mathrm{r}_{\mathrm{i}, \mathrm{t}}\right)$ ' is a vector of stock returns measured at time $t$, with $\mathrm{r}_{\mathrm{us}, \mathrm{t}}$ representing U.S. stock market returns and $\mathrm{r}_{\mathrm{i}, \mathrm{t}}, i=1$ to 10 , denoting the other stock 
market return employed in the market pair. $\Omega$ is a $(2 \times 1)$ vector of constants and $\Phi$ is a $(2 \times 2)$ matrix of estimated coefficients that captures persistence and cross-country effects in the conditional mean of returns. $\varepsilon_{t}$ is a vector of error terms, while $\eta$ is defined as $\operatorname{Min}\left(0, \varepsilon_{t}\right)$ and is designed to pick out the 'bad' news events as they hit the market. $\theta$ is a $(2 \times 2)$ diagonal coefficient matrix whose elements measure the additional effects of adverse shocks on the level of returns. The errors are normally distributed with zero mean and a time-varying conditional covariance matrix, $\mathrm{H}_{\mathrm{t}} . \mathrm{H}_{\mathrm{t}}$ is modelled as a GARCH $(1,1)$ process with an additional term to capture asymmetric effects as given in equation (1). C, A, B and $\Gamma$ are all square matrices of coefficients. The asymmetric effects of bad news on the volatility processes are captured by the $\Gamma$ matrix.

As our ultimate focus is on the evolution of the conditional correlations over the period, we use the above model to generate these as:

$$
\rho_{u s, i, t}=\frac{h_{u s, i, t}}{\sqrt{h_{u s, t}} \sqrt{h_{i, t}}} .
$$

\subsection{Data}

We employ weekly stock price indices for a sample of eleven countries. The total market indices are decomposed into two broadly defined sectors, namely financial and non-financial stocks. We initially focus on the financial sector but later extend our analysis to non-financial stocks. We choose to work with a broad index of financial stocks rather than just choosing a finer industry classification such as banks, given that the recent crisis has severely impaired the operations not only of banks but also of firms operating in the insurance and other non-banking sectors. For example the insurance giant AIG has received significant bail-outs from the Federal Reserve System. ${ }^{3}$ Our sample encompasses both developed and developing markets as we seek to assess any differences in correlation dynamics across countries that vary in their degree of financial sophistication. All indices are value-weighted, expressed in local currency and have been obtained from Datastream International. The Datastream codes have the following structure: FINANXX and TOTLIXX represent the index of financial and non-financial stocks respectively, where XX represents the country code, United States (US), United Kingdom (UK), Canada (CN), Germany (BD), Japan (JP), Ireland (IR), Greece (GR), Poland (PO), HongKong (HK), Singapore (SG), and Malaysia (MA). We employ weekly returns rather than daily returns in order to reduce the effects of non-synchronous trading between markets. Returns are computed as the change in the log price between two consecutive trading periods.

\footnotetext{
${ }^{3}$ We repeat the analysis using only banking stocks and the observed patterns are similar.
} 
Table 1: Summary Descriptive Statistics

\begin{tabular}{|c|c|c|c|c|c|c|c|}
\hline \multicolumn{8}{|c|}{ Panel A: Financial Returns } \\
\hline & Mean & Variance & Min & Max & Skewness & Kurtosis & Jarque-Bera \\
\hline US & -0.0001 & 0.001 & -0.20 & 0.26 & $0.25 * * *$ & $9.95 * * *$ & $2162.79 * * *$ \\
\hline UK & -0.0002 & 0.001 & -0.24 & 0.16 & $-0.87 * * *$ & $8.92 * * *$ & $1800.40 * * *$ \\
\hline $\mathbf{C N}$ & 0.001 & 0.0006 & -0.18 & 0.18 & $-0.52 * * *$ & $13.04 * * *$ & $3727.41 * * *$ \\
\hline BD & -0.0006 & 0.001 & -0.24 & 0.17 & $-0.57 * * *$ & $7.14^{* * *}$ & $1140.07 * * *$ \\
\hline JP & -0.0002 & 0.001 & -0.18 & 0.11 & -0.07 & $1.08 * * *$ & $25.97 * * *$ \\
\hline IR & -0.002 & 0.002 & -0.46 & 0.35 & $-1.53 * * *$ & $18.81^{* * *}$ & $7900.99 * * *$ \\
\hline GR & -0.0003 & 0.001 & -0.24 & 0.27 & $0.22 * *$ & $6.18 * * *$ & $837.32 * * *$ \\
\hline PO & 0.002 & 0.001 & -0.17 & 0.19 & -0.17 & $3.35 * * *$ & $247.45^{* * *}$ \\
\hline HK & 0.001 & 0.001 & -0.14 & 0.14 & $-0.20 * *$ & $2.43 * * *$ & $133.16^{* * *}$ \\
\hline SG & 0.001 & 0.001 & -0.15 & 0.16 & $-0.31 * * *$ & $2.32 * * *$ & $126.33 * * *$ \\
\hline MY & 0.002 & 0.0009 & -0.12 & 0.18 & $0.45 * * *$ & $4.73 * * *$ & $506.52 * * *$ \\
\hline \multicolumn{8}{|c|}{ Panel B: Non-Financial Returns } \\
\hline US & 0.00008 & 0.0007 & -0.17 & 0.10 & $-0.85 * * *$ & $6.41 * * *$ & $958.80 * * *$ \\
\hline UK & 0.0006 & 0.0005 & -0.18 & 0.12 & $-0.58 * * *$ & $9.24 * * *$ & $1888.00 * * *$ \\
\hline $\mathbf{C N}$ & 0.001 & 0.0008 & -0.15 & 0.12 & $-0.79 * * *$ & $5.55^{* * *}$ & $726.16^{* * *}$ \\
\hline BD & 0.0005 & 0.0009 & -0.16 & 0.21 & 0.02 & $6.58 * * *$ & $942.73 * * *$ \\
\hline JP & 0.0001 & 0.0007 & -0.20 & 0.10 & $-0.87 * * *$ & $5.22 * * *$ & $660.31 * * *$ \\
\hline IR & 0.0001 & 0.001 & -0.18 & 0.10 & $-1.08 * * *$ & $4.82 * * *$ & $609.51 * * *$ \\
\hline GR & 0.0001 & 0.001 & -0.14 & 0.21 & $0.35 * * *$ & $5.39 * * *$ & $643.00 * * *$ \\
\hline PO & 0.001 & 0.001 & -0.12 & 0.19 & $0.31 * * *$ & $1.70 * * *$ & $72.15^{* * *}$ \\
\hline HK & 0.002 & 0.001 & -0.16 & 0.15 & -0.05 & $2.18 * * *$ & $104.06 * * *$ \\
\hline SG & 0.0009 & 0.0007 & -0.16 & 0.14 & $-0.35 * * *$ & $4.08 * * *$ & $373.82 * * *$ \\
\hline MY & 0.001 & 0.0006 & -0.09 & 0.11 & 0.05 & $2.61 * * *$ & $148.97 * * *$ \\
\hline
\end{tabular}


Table 1 presents descriptive statistics for the weekly returns. Panels A and B refer to returns on financial and non-financial stocks respectively. For financial stocks, the returns of US, UK, Japan, Germany, Ireland and Greece are on average negative over the sample. This outcome is driven predominantly by the poor performance of this sector over the period 2007-2009. In contrast, all of the nonfinancial sectors have positive mean returns. As usual, the returns of all sectors are found to be noisy and exhibit large degrees of non-normality.

Before analyzing the cross-country co-movements of these sectors, we first investigate the relative importance of financial and non-financial stocks in the total market index of our sampled countries. Figure 1 presents this information with the lower segment (lighter colour) representing the proportion of total market value attributed to financial stocks.

In the larger markets, such as US, UK, Canada, Germany and Japan, and also in Malaysia financial stocks account for between 20 percent and 30 percent of total value over the sampled period. In these countries, there was a modest decline in its relative importance during the recent crisis, indicating that financial stocks declined in market value at a slightly quicker rate than non-financial stocks over this period. For the other smaller markets, the relative contribution to market value from financial stocks was much greater. In both Poland and Ireland, this sector's weight in the total market reached almost 60 percent. With the exception of Ireland, and to a lesser extent Greece, the rate of decline of market capitalization in both sectors was approximately the same. However in Ireland, the collapse of the financial sector has been spectacular. In a declining market, the contribution of the sector has fallen from a high of about 58 percent in late 2002 to about 6 percent in early $2009 .{ }^{4}$ Therefore it is clear that the importance of the financial sector differs greatly across our sample of countries.

\section{Empirical Results: Financial Stocks}

\subsection{Conditional Mean}

Our estimates of the conditional mean process are presented in panel A of Table 2. As usual, returns at this frequency are almost serially independent. The effects of own lagged returns on current values are largely not statistically significant. However, there is evidence that the lagged U.S. return has some explanatory power in other markets, which tend to follow in the same direction as U.S. returns. This is consistent with the idea that the United States is a leader country and exerts a global influence. Interestingly, the only exception is Malaysia which became more segmented from global markets following its decision to impose capital controls during the Asian crisis. Furthermore, we find that in many instances, negative news in the previous period has a persistent influence on current stock returns. We find

\footnotetext{
${ }^{4}$ Irish banks were hugely exposed to the housing and construction sector, which experienced huge declines since 2007. The two largest banks lost over 90 percent of their market capitalization between 2007 and early 2009 .
} 
statistically significant evidence of this for US returns in eight of the ten pairs investigated and for four of the other country returns. Therefore, adverse shocks have the greatest impact on US returns, while lagged US returns are the most important predictor of returns in the other markets.

\subsection{Conditional Second-order Moments}

Panel B of Table 2 contains the parameters governing the evolution of the conditional covariance matrices. For all of the markets analyzed, there is strong evidence of time-variation with most of the ARCH effects (A matrix) and the persistence parameters (B matrix) statistically different from zero. This finding is strongest for the diagonal elements implying that there is a strong tendency for the conditional variance of equity returns in all of the markets analyzed to deviate from their unconditional values in the short-term. However, a sufficient number of covariance parameters are statistically significant to justify our modeling approach. Interestingly, for all country pairs, we find evidence of an asymmetric response to positive and negative shocks. As hypothesized, bad news events increase asset return volatility with evidence that the conditional covariances are more sensitive to adverse rather than positive shocks ( $\Gamma$ matrix). There is much evidence in the extant literature that economic recessions increase stock market volatility, for example Schwert (1989) and Campbell et al. (2001), and our results are consistent with this stylized fact.

\subsection{Conditional Correlations}

From our estimates, we recover the time-varying conditional correlations for each pair of countries and these are presented in Figure 2. For each pair analyzed, we show the conditional correlation (dashed line) together with a filtered series (full line) that is designed to highlight long-run trends in the series. ${ }^{5}$

There are a number of striking features. Firstly, there is considerable timevariation in the conditional correlations of all country pairs. Consistent with the findings of Bordo and Murschid (2000), this temporal variation is found both in times of crisis and periods of relative tranquility. Therefore changes in correlation are not exclusive to periods of high asset return volatility. Secondly, there is much higher correlation between US financial returns and those of its traditional trading partners such as the UK and Canada rather than the more recently emerged markets of Greece, Poland and Malaysia. In terms of the financial institutions underlying our indices, it is arguable that financial sectors with similar levels of sophistication and development exhibit higher degrees of co-movement, while countries that may be characterized by less developed financial systems have a lower tendency to co-move with the US. Thirdly, the conditional correlations generated exhibit a similar pattern across country pairs. In the early part of our sample, correlations decreased as we

\footnotetext{
${ }^{5}$ The filtered series is extracted using the Hodrick-Prescott filter.
} 


\begin{tabular}{|c|c|c|c|c|c|c|c|c|c|c|}
\hline \multicolumn{11}{|c|}{ Panel A: Mean Equation } \\
\hline & US-UK & US-CN & US-BD & US-JP & US-IR & US-GR & US-PO & US-HK & US-SG & US-MY \\
\hline$\omega_{U S}$ & $\begin{array}{c}0.0007 \\
(0.73)\end{array}$ & $\begin{array}{c}- \\
0.00003 \\
(-0.10)\end{array}$ & $\begin{array}{c}0.0004 \\
(0.58)\end{array}$ & $\begin{array}{c}0.0002 \\
(0.21)\end{array}$ & $\begin{array}{c}0.0004 \\
(0.41)\end{array}$ & $\begin{array}{c}-0.0001 \\
(-0.15)\end{array}$ & $\begin{array}{l}-0.001 \\
(-1.13)\end{array}$ & $\begin{array}{c}- \\
0.00006 \\
(-0.05)\end{array}$ & $\begin{array}{c}-0.0002 \\
(-0.26)\end{array}$ & $\begin{array}{c}-0.0008 \\
(-0.97)\end{array}$ \\
\hline$\phi_{U S, U S}$ & $\begin{array}{l}-0.008 \\
(-0.14)\end{array}$ & $\begin{array}{c}-0.01 \\
(-0.16)\end{array}$ & $\begin{array}{c}-0.04 \\
(-0.76)\end{array}$ & $\begin{array}{c}-0.01 \\
(-0.26)\end{array}$ & $\begin{array}{c}0.02 \\
(0.38)\end{array}$ & $\begin{array}{l}0.007 \\
(0.11)\end{array}$ & $\begin{array}{c}0.02 \\
(0.43)\end{array}$ & $\begin{array}{c}0.01 \\
(0.36)\end{array}$ & $\begin{array}{c}0.03 \\
(0.85)\end{array}$ & $\begin{array}{c}0.01 \\
(0.20)\end{array}$ \\
\hline$\phi_{U S, i}$ & $\begin{array}{l}0.005 \\
(0.08)\end{array}$ & $\begin{array}{c}0.04 \\
(0.49)\end{array}$ & $\begin{array}{c}-0.01 \\
(-0.28)\end{array}$ & $\begin{array}{c}-0.04 \\
(-1.71)\end{array}$ & $\begin{array}{c}-0.05 \\
(-2.06)\end{array}$ & $\begin{array}{c}-0.02 \\
(-1.10)\end{array}$ & $\begin{array}{l}0.007 \\
(0.27)\end{array}$ & $\begin{array}{l}0.002 \\
(0.06)\end{array}$ & $\begin{array}{c}-0.09 \\
(-2.63)\end{array}$ & $\begin{array}{l}0.005 \\
(0.13)\end{array}$ \\
\hline$\theta_{U S, U S}$ & $\begin{array}{c}-0.10 \\
(-1.32)\end{array}$ & $\begin{array}{c}-0.16 \\
(-3.27)\end{array}$ & $\begin{array}{c}-0.11 \\
(-1.83)\end{array}$ & $\begin{array}{c}-0.09 \\
(-0.91)\end{array}$ & $\begin{array}{c}-0.17 \\
(-1.90)\end{array}$ & $\begin{array}{c}-0.17 \\
(-1.79)\end{array}$ & $\begin{array}{c}-0.21 \\
(-2.04)\end{array}$ & $\begin{array}{c}-0.20 \\
(-2.19)\end{array}$ & $\begin{array}{c}-0.19 \\
(-3.09)\end{array}$ & $\begin{array}{c}-0.17 \\
(-2.07)\end{array}$ \\
\hline$\omega_{i}$ & $\begin{array}{l}0.001 \\
(0.76)\end{array}$ & $\begin{array}{l}0.003 \\
(1.69)\end{array}$ & $\begin{array}{l}0.003 \\
(2.60)\end{array}$ & $\begin{array}{l}-0.003 \\
(-2.79)\end{array}$ & $\begin{array}{c}0.0004 \\
(0.26)\end{array}$ & $\begin{array}{l}0.002 \\
(0.99)\end{array}$ & $\begin{array}{l}0.004 \\
(1.75)\end{array}$ & $\begin{array}{c}-0.0005 \\
(-0.49)\end{array}$ & $\begin{array}{l}0.001 \\
(0.90)\end{array}$ & $\begin{array}{c}0.0004 \\
(0.34)\end{array}$ \\
\hline$\phi_{i, i}$ & $\begin{array}{c}-0.13 \\
(-2.11)\end{array}$ & $\begin{array}{c}-0.14 \\
(-0.98)\end{array}$ & $\begin{array}{c}-0.17 \\
(-2.60)\end{array}$ & $\begin{array}{c}0.04 \\
(0.88)\end{array}$ & $\begin{array}{c}-0.05 \\
(-0.90)\end{array}$ & $\begin{array}{c}-0.03 \\
(-0.40)\end{array}$ & $\begin{array}{c}-0.04 \\
(-0.49)\end{array}$ & $\begin{array}{c}0.09 \\
(1.67)\end{array}$ & $\begin{array}{c}0.03 \\
(0.54)\end{array}$ & $\begin{array}{c}0.11 \\
(1.32)\end{array}$ \\
\hline$\phi_{i, U S}$ & $\begin{array}{c}0.20 \\
(3.60)\end{array}$ & $\begin{array}{c}0.10 \\
(3.29)\end{array}$ & $\begin{array}{c}0.09 \\
(1.92)\end{array}$ & $\begin{array}{c}0.16 \\
(4.43)\end{array}$ & $\begin{array}{c}0.21 \\
(6.25)\end{array}$ & $\begin{array}{c}0.14 \\
(1.90)\end{array}$ & $\begin{array}{c}0.09 \\
(2.31)\end{array}$ & $\begin{array}{c}0.18 \\
(4.70)\end{array}$ & $\begin{array}{c}0.19 \\
(3.97)\end{array}$ & $\begin{array}{c}0.15 \\
(4.06)\end{array}$ \\
\hline$\theta_{i, i}$ & $\begin{array}{c}-0.02 \\
(-0.20)\end{array}$ & $\begin{array}{c}0.04 \\
(0.32)\end{array}$ & $\begin{array}{c}0.21 \\
(1.79)\end{array}$ & $\begin{array}{c}-0.24 \\
(-3.53)\end{array}$ & $\begin{array}{c}-0.15 \\
(-1.80)\end{array}$ & $\begin{array}{c}0.07 \\
(0.60)\end{array}$ & $\begin{array}{c}0.11 \\
(0.75)\end{array}$ & $\begin{array}{c}-0.30 \\
(-3.36)\end{array}$ & $\begin{array}{c}-0.14 \\
(-1.11)\end{array}$ & $\begin{array}{c}-0.10 \\
(-0.84)\end{array}$ \\
\hline
\end{tabular}




\begin{tabular}{|c|c|c|c|c|c|c|c|c|c|c|}
\hline \multicolumn{11}{|c|}{ Panel B: Variance Equation } \\
\hline & US-UK & US-CN & US-BD & US-JP & US-IR & US-GR & US-PO & US-HK & US- SG & US-MY \\
\hline$c_{U S, U S}$ & $\begin{array}{l}0.002 \\
(3.02)\end{array}$ & $\begin{array}{l}0.003 \\
(3.55)\end{array}$ & $\begin{array}{l}0.002 \\
(1.89)\end{array}$ & $\begin{array}{l}0.002 \\
(1.67)\end{array}$ & $\begin{array}{l}0.004 \\
(2.63)\end{array}$ & $\begin{array}{l}0.003 \\
(3.10)\end{array}$ & $\begin{array}{l}0.004 \\
(3.06)\end{array}$ & $\begin{array}{l}0.004 \\
(3.79)\end{array}$ & $\begin{array}{c}0.003 \\
(1.99)\end{array}$ & $\begin{array}{l}0.002 \\
(1.87)\end{array}$ \\
\hline$C_{U S, i}$ & $\begin{array}{l}0.002 \\
(2.73)\end{array}$ & $\begin{array}{l}0.001 \\
(3.37)\end{array}$ & $\begin{array}{l}0.004 \\
(5.34)\end{array}$ & $\begin{array}{c}-0.0008 \\
(-0.47)\end{array}$ & $\begin{array}{l}0.003 \\
(2.37)\end{array}$ & $\begin{array}{l}0.003 \\
(1.78)\end{array}$ & $\begin{array}{l}0.002 \\
(1.91)\end{array}$ & $\begin{array}{l}0.002 \\
(2.69)\end{array}$ & $\begin{array}{c}0.003 \\
(2.23)\end{array}$ & $\begin{array}{l}0.002 \\
(1.94)\end{array}$ \\
\hline$C_{i, i}$ & $\begin{array}{l}0.004 \\
(5.11)\end{array}$ & $\begin{array}{l}0.003 \\
(2.94)\end{array}$ & $\begin{array}{l}0.006 \\
(5.76)\end{array}$ & $\begin{array}{c}0.01 \\
(2.30)\end{array}$ & $\begin{array}{l}0.005 \\
(4.24)\end{array}$ & $\begin{array}{c}0.01 \\
(3.77)\end{array}$ & $\begin{array}{c}0.01 \\
(2.66)\end{array}$ & $\begin{array}{l}0.004 \\
(4.77)\end{array}$ & $\begin{array}{c}0.0007 \\
(0.23)\end{array}$ & $\begin{array}{c}-0.0003 \\
(-0.21)\end{array}$ \\
\hline$a_{U S, U S}$ & $\begin{array}{c}0.10 \\
(1.86)\end{array}$ & $\begin{array}{c}0.11 \\
(1.87)\end{array}$ & $\begin{array}{c}0.08 \\
(1.16)\end{array}$ & $\begin{array}{c}0.13 \\
(1.97)\end{array}$ & $\begin{array}{c}-0.11 \\
(-1.34)\end{array}$ & $\begin{array}{c}0.06 \\
(1.01)\end{array}$ & $\begin{array}{c}-0.11 \\
(-1.13)\end{array}$ & $\begin{array}{c}0.16 \\
(3.77)\end{array}$ & $\begin{array}{c}-0.09 \\
(-1.18)\end{array}$ & $\begin{array}{c}0.01 \\
(0.16)\end{array}$ \\
\hline$a_{U S, i}$ & $\begin{array}{c}-0.07 \\
(-2.63)\end{array}$ & $\begin{array}{c}-0.13 \\
(-2.91)\end{array}$ & $\begin{array}{c}-0.07 \\
(-2.40)\end{array}$ & $\begin{array}{c}-0.07 \\
(-2.38)\end{array}$ & $\begin{array}{c}0.02 \\
(0.38)\end{array}$ & $\begin{array}{l}0.002 \\
(0.08)\end{array}$ & $\begin{array}{c}0.05 \\
(0.91)\end{array}$ & $\begin{array}{c}-0.09 \\
(-3.34)\end{array}$ & $\begin{array}{c}0.12 \\
(2.91)\end{array}$ & $\begin{array}{c}0.03 \\
(1.52)\end{array}$ \\
\hline$a_{i, i}$ & $\begin{array}{c}-0.09 \\
(-2.40)\end{array}$ & $\begin{array}{l}0.008 \\
(0.18)\end{array}$ & $\begin{array}{c}-0.11 \\
(-1.47)\end{array}$ & $\begin{array}{c}-0.25 \\
(-3.48)\end{array}$ & $\begin{array}{c}0.20 \\
(2.31)\end{array}$ & $\begin{array}{c}0.29 \\
(3.81)\end{array}$ & $\begin{array}{c}0.19 \\
(2.12)\end{array}$ & $\begin{array}{c}0.14 \\
(2.69)\end{array}$ & $\begin{array}{c}0.19 \\
(2.16)\end{array}$ & $\begin{array}{c}0.23 \\
(6.26)\end{array}$ \\
\hline$\beta_{U S, U S}$ & $\begin{array}{c}0.94 \\
(66.81)\end{array}$ & $\begin{array}{c}0.93 \\
(36.65)\end{array}$ & $\begin{array}{c}0.93 \\
(63.99)\end{array}$ & $\begin{array}{c}0.92 \\
(37.12)\end{array}$ & $\begin{array}{c}0.90 \\
(21.53)\end{array}$ & $\begin{array}{c}0.91 \\
(34.23)\end{array}$ & $\begin{array}{c}0.91 \\
(19.79)\end{array}$ & $\begin{array}{c}0.90 \\
(33.27)\end{array}$ & $\begin{array}{c}0.89 \\
(28.66)\end{array}$ & $\begin{array}{c}0.93 \\
(31.89)\end{array}$ \\
\hline$\beta_{U S, i}$ & $\begin{array}{c}-0.01 \\
(-1.02)\end{array}$ & $\begin{array}{l}-0.009 \\
(-1.03)\end{array}$ & $\begin{array}{c}-0.04 \\
(-2.07)\end{array}$ & $\begin{array}{c}0.01 \\
(0.82)\end{array}$ & $\begin{array}{c}-0.03 \\
(-1.17)\end{array}$ & $\begin{array}{c}-0.03 \\
(-1.13)\end{array}$ & $\begin{array}{c}-0.03 \\
(-1.14)\end{array}$ & $\begin{array}{c}-0.02 \\
(-1.60)\end{array}$ & $\begin{array}{c}-0.02 \\
(-0.83)\end{array}$ & $\begin{array}{c}-0.01 \\
(-0.73)\end{array}$ \\
\hline$\beta_{i, i}$ & $\begin{array}{c}0.91 \\
(49.36)\end{array}$ & $\begin{array}{c}0.91 \\
(23.16)\end{array}$ & $\begin{array}{c}0.87 \\
(39.19)\end{array}$ & $\begin{array}{c}0.89 \\
(15.13)\end{array}$ & $\begin{array}{c}0.92 \\
(43.19)\end{array}$ & $\begin{array}{c}0.87 \\
(17.97)\end{array}$ & $\begin{array}{c}0.79 \\
(5.63)\end{array}$ & $\begin{array}{c}0.94 \\
(65.74)\end{array}$ & $\begin{array}{c}0.95 \\
(27.74)\end{array}$ & $\begin{array}{c}0.96 \\
(97.78)\end{array}$ \\
\hline$\gamma_{U S, U S}$ & $\begin{array}{c}0.36 \\
(6.40)\end{array}$ & $\begin{array}{c}0.35 \\
(5.70)\end{array}$ & $\begin{array}{c}0.44 \\
(7.94)\end{array}$ & $\begin{array}{c}0.51 \\
(7.51)\end{array}$ & $\begin{array}{c}0.46 \\
(5.34)\end{array}$ & $\begin{array}{c}0.47 \\
(7.53)\end{array}$ & $\begin{array}{c}0.48 \\
(5.60)\end{array}$ & $\begin{array}{c}0.48 \\
(7.52)\end{array}$ & $\begin{array}{c}0.48 \\
(8.32)\end{array}$ & $\begin{array}{c}0.46 \\
(5.05)\end{array}$ \\
\hline$\gamma_{U S, i}$ & $\begin{array}{c}0.14 \\
(2.63)\end{array}$ & $\begin{array}{c}0.25 \\
(4.26)\end{array}$ & $\begin{array}{c}0.12 \\
(1.98)\end{array}$ & $\begin{array}{c}-0.02 \\
(-0.76)\end{array}$ & $\begin{array}{c}0.13 \\
(1.42)\end{array}$ & $\begin{array}{c}0.11 \\
(2.48)\end{array}$ & $\begin{array}{c}0.13 \\
(1.51)\end{array}$ & $\begin{array}{c}0.14 \\
(3.08)\end{array}$ & $\begin{array}{c}0.16 \\
(2.56)\end{array}$ & $\begin{array}{c}0.05 \\
(0.99)\end{array}$ \\
\hline$\gamma_{i, i}$ & $\begin{array}{c}0.40 \\
(6.43) \\
\end{array}$ & $\begin{array}{c}0.13 \\
(2.07) \\
\end{array}$ & $\begin{array}{c}0.53 \\
(7.21) \\
\end{array}$ & $\begin{array}{c}0.25 \\
(2.84) \\
\end{array}$ & $\begin{array}{c}0.38 \\
(4.50) \\
\end{array}$ & $\begin{array}{c}0.25 \\
(2.14) \\
\end{array}$ & $\begin{array}{c}0.43 \\
(4.39) \\
\end{array}$ & $\begin{array}{c}0.31 \\
(4.78) \\
\end{array}$ & $\begin{array}{c}0.11 \\
(0.82) \\
\end{array}$ & $\begin{array}{c}0.09 \\
(1.79) \\
\end{array}$ \\
\hline
\end{tabular}

Equation (1) is estimated by maximum likelihood with optimization performed using the BFGS algorithm. Robust $\boldsymbol{t}$ - tests are reported in parentheses. Entries that are statistically different from zero at the $10 \%$ confidence level are represented in bold. 
Figure 1: Market Capitalisation of Financial and Non-financial Stocks as a Proportion of Total Market Capitalisation
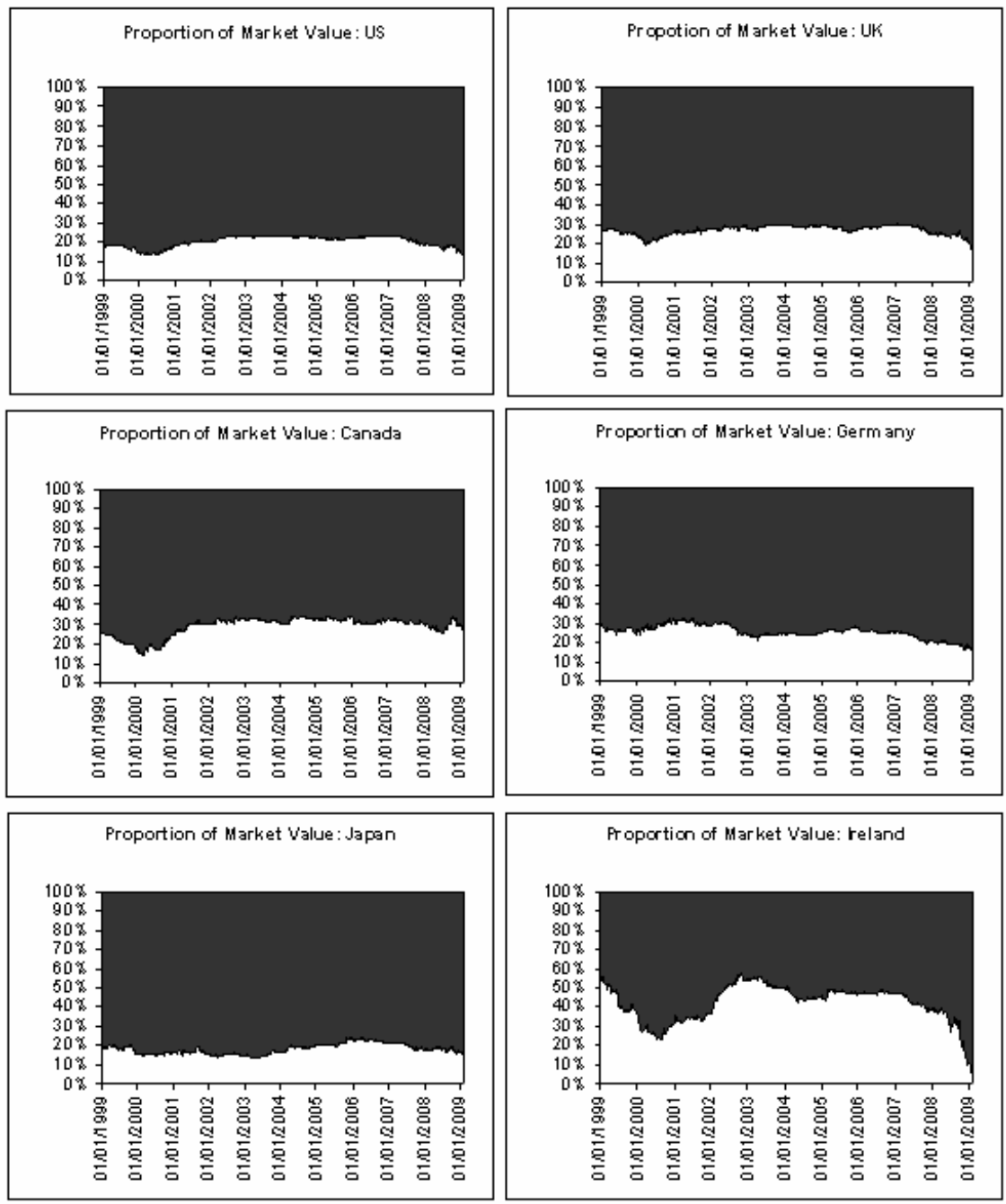

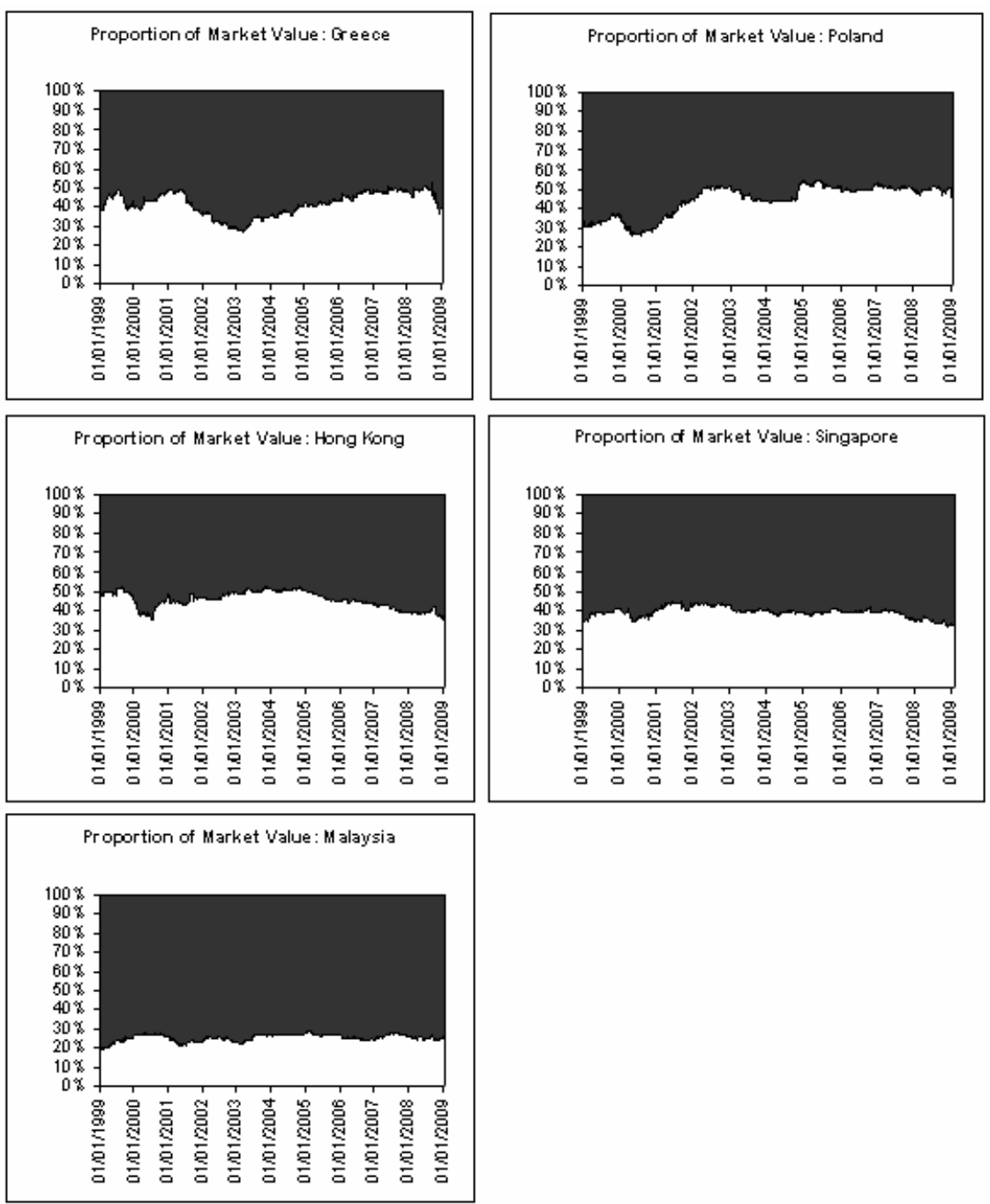
Figure 2: Time-varying Cross-country Conditional Correlations of Financial Stock Returns
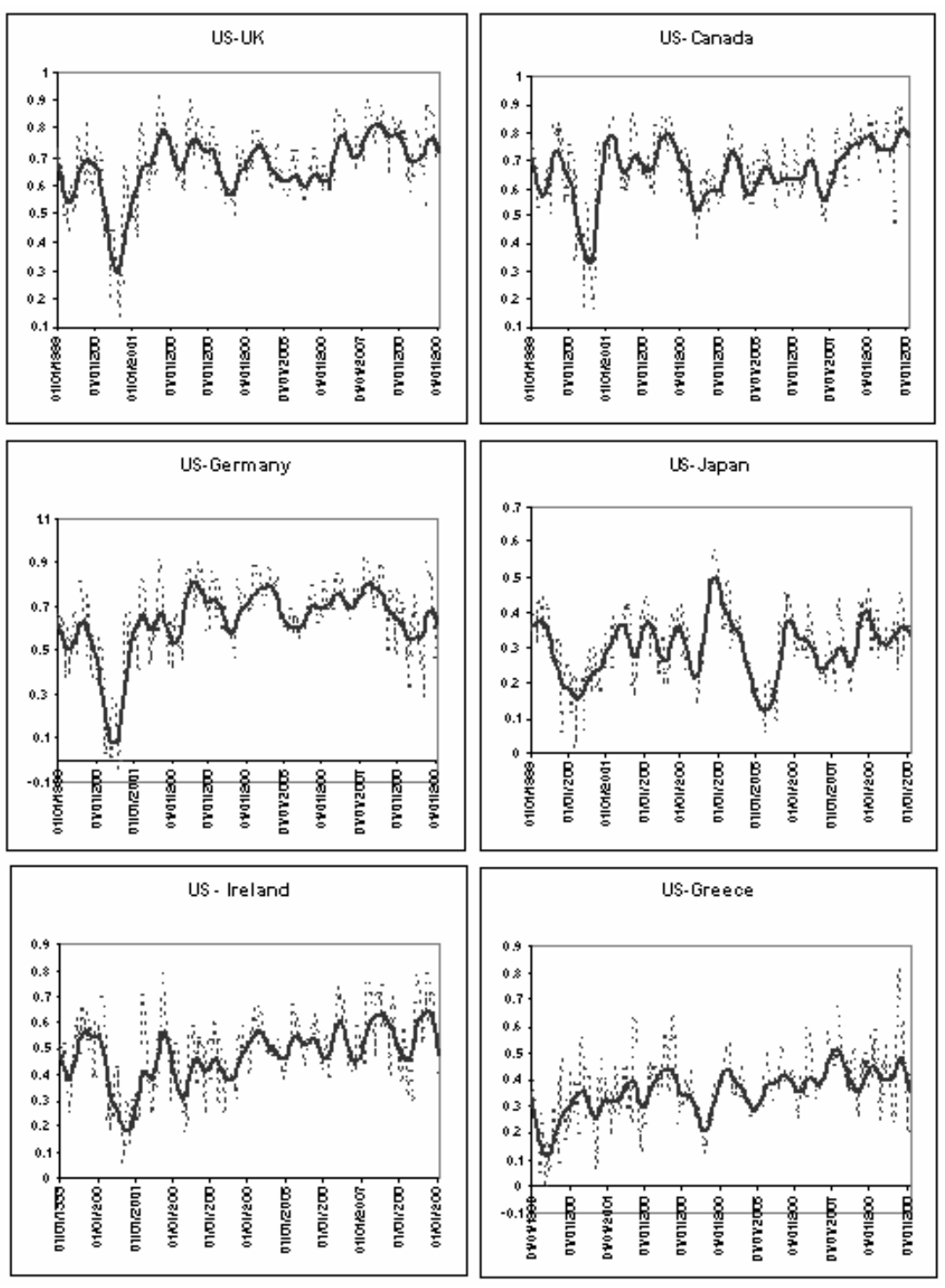

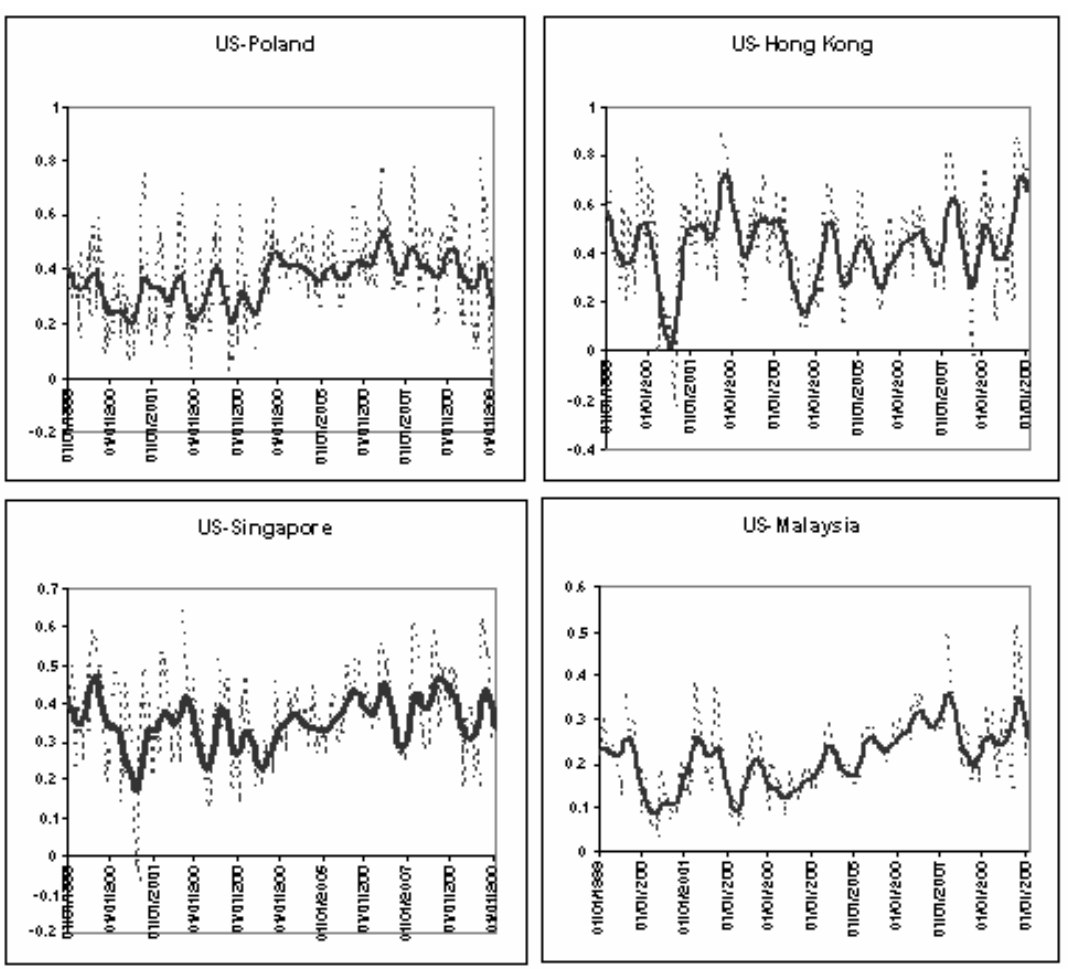

suffered a number of regional crises such as bond market shocks originating in Brazil and Argentina and there may also have been an overhang from the Asian crisis of 1997-98. These crises led to large changes in market co-movements as international financial stocks responded to these shocks. However, the period of 2001-02 was characterized by increasing correlations for all pairs as all markets experienced a period of turmoil with the collapse of the dot.com bubble and Long Term Capital Management (LTCM) hedge fund. These were predominantly US shocks but such is the global influence of the US that there is increased correlation across all pairs. Only the then fledgling Polish market bucked that trend. In the aftermath of these shocks, there was a general downward trend in levels of co-movement between markets in what were relatively tranquil financial markets and benign economic conditions.

As expected, the period of the recent 'credit crunch' is characterized by a sharp increase in conditional correlations. This pattern is observed for all pairs with the US, though the increase is relatively modest in the emerging or recently emerged markets of Poland, Singapore and Malaysia. In all other markets, there is a strong upward trend in our measure of co-movement. Interestingly, however, these increases only return correlations to levels recorded during the dot.com and LTCM 
Table 3: Parameter Estimates for Model with Non-Financial Stock Returns

\begin{tabular}{|c|c|c|c|c|c|c|c|c|c|c|}
\hline & US-UK & US-CN & US-BD & US-JP & US- IR & US-GR & US-PO & US-HK & US-SG & US-MY \\
\hline$\omega_{U S}$ & $\begin{array}{c}-0.0003 \\
(-0.37)\end{array}$ & $\begin{array}{c}-0.00004 \\
(-0.04)\end{array}$ & $\begin{array}{c}0.0001 \\
(0.16)\end{array}$ & $\begin{array}{c}0.0008 \\
(0.81)\end{array}$ & $\begin{array}{l}0.001 \\
(1.07)\end{array}$ & $\begin{array}{c}0.0007 \\
(0.77)\end{array}$ & $\begin{array}{c}-0.0003 \\
(-0.43)\end{array}$ & $\begin{array}{l}0.001 \\
(0.63)\end{array}$ & $\begin{array}{c}-0.0002 \\
(-0.19)\end{array}$ & $\begin{array}{c}0.0001 \\
(0.18)\end{array}$ \\
\hline$\phi_{U S, U S}$ & $\begin{array}{c}-0.08 \\
(-1.28)\end{array}$ & $\begin{array}{c}-0.08 \\
(-0.81)\end{array}$ & $\begin{array}{c}-0.07 \\
(-0.90)\end{array}$ & $\begin{array}{c}-0.08 \\
(-1.31)\end{array}$ & $\begin{array}{c}-0.13 \\
(-2.38)\end{array}$ & $\begin{array}{c}-0.08 \\
(-1.55)\end{array}$ & $\begin{array}{c}-0.03 \\
(-0.51)\end{array}$ & $\begin{array}{c}-0.13 \\
(-1.51)\end{array}$ & $\begin{array}{c}0.01 \\
(0.23)\end{array}$ & $\begin{array}{c}-0.14 \\
(-2.15)\end{array}$ \\
\hline$\phi_{U S, i}$ & $\begin{array}{c}0.12 \\
(2.18)\end{array}$ & $\begin{array}{c}0.02 \\
(0.39)\end{array}$ & $\begin{array}{c}0.05 \\
(0.88)\end{array}$ & $\begin{array}{c}-0.03 \\
(-0.77)\end{array}$ & $\begin{array}{c}0.03 \\
(0.93)\end{array}$ & $\begin{array}{c}0.01 \\
(0.44)\end{array}$ & $\begin{array}{c}0.04 \\
(1.51)\end{array}$ & $\begin{array}{c}0.03 \\
(0.92)\end{array}$ & $\begin{array}{c}-0.01 \\
(-0.27)\end{array}$ & $\begin{array}{c}0.08 \\
(1.20)\end{array}$ \\
\hline$\theta_{U S, U S}$ & $\begin{array}{c}-0.14 \\
(-1.78)\end{array}$ & $\begin{array}{c}-0.09 \\
(-0.98)\end{array}$ & $\begin{array}{c}-0.12 \\
(-1.11)\end{array}$ & $\begin{array}{c}0.06 \\
(0.65)\end{array}$ & $\begin{array}{c}0.03 \\
(0.40)\end{array}$ & $\begin{array}{l}-0.001 \\
(-0.01)\end{array}$ & $\begin{array}{c}-0.13 \\
(-1.70)\end{array}$ & $\begin{array}{l}0.009 \\
(0.05)\end{array}$ & $\begin{array}{c}-0.18 \\
(-1.66)\end{array}$ & $\begin{array}{c}0.02 \\
(0.20)\end{array}$ \\
\hline$\omega_{i}$ & $\begin{array}{c}0.0008 \\
(0.82)\end{array}$ & $\begin{array}{l}0.002 \\
(1.63)\end{array}$ & $\begin{array}{l}0.001 \\
(0.92)\end{array}$ & $\begin{array}{l}-0.002 \\
(-1.26)\end{array}$ & $\begin{array}{l}0.002 \\
(0.88)\end{array}$ & $\begin{array}{c}-0.00006 \\
(-0.03)\end{array}$ & $\begin{array}{c}-0.0003 \\
(-0.15)\end{array}$ & $\begin{array}{c}-0.0001 \\
(-0.10)\end{array}$ & $\begin{array}{c}-0.0001 \\
(-0.13)\end{array}$ & $\begin{array}{l}0.001 \\
(0.87)\end{array}$ \\
\hline$\phi_{i, i}$ & $\begin{array}{c}-0.10 \\
(-1.80)\end{array}$ & $\begin{array}{c}-0.09 \\
(-0.94)\end{array}$ & $\begin{array}{c}-0.08 \\
(-0.95)\end{array}$ & $\begin{array}{c}0.02 \\
(0.33)\end{array}$ & $\begin{array}{c}-0.07 \\
(-0.82)\end{array}$ & $\begin{array}{c}0.09 \\
(1.47)\end{array}$ & $\begin{array}{c}0.07 \\
(0.83)\end{array}$ & $\begin{array}{c}0.04 \\
(0.51)\end{array}$ & $\begin{array}{c}0.09 \\
(2.72)\end{array}$ & $\begin{array}{c}0.04 \\
(0.28)\end{array}$ \\
\hline$\phi_{i, U S}$ & $\begin{array}{c}0.10 \\
(2.15)\end{array}$ & $\begin{array}{c}0.06 \\
(0.83)\end{array}$ & $\begin{array}{c}0.14 \\
(1.90)\end{array}$ & $\begin{array}{c}0.18 \\
(3.46)\end{array}$ & $\begin{array}{c}0.11 \\
(1.69)\end{array}$ & $\begin{array}{c}0.18 \\
(2.44)\end{array}$ & $\begin{array}{c}0.20 \\
(3.50)\end{array}$ & $\begin{array}{c}0.35 \\
(4.41)\end{array}$ & $\begin{array}{c}0.21 \\
(5.00)\end{array}$ & $\begin{array}{c}0.09 \\
(2.70)\end{array}$ \\
\hline$\theta_{i, i}$ & $\begin{array}{c}-0.04 \\
(-0.44)\end{array}$ & $\begin{array}{c}0.001 \\
(0.009)\end{array}$ & $\begin{array}{c}-0.03 \\
(-0.26)\end{array}$ & $\begin{array}{l}-0.21 \\
(1.48)\end{array}$ & $\begin{array}{c}0.10 \\
(0.49)\end{array}$ & $\begin{array}{c}-0.10 \\
(-1.02)\end{array}$ & $\begin{array}{c}-0.10 \\
(-0.76)\end{array}$ & $\begin{array}{c}-0.28 \\
(-2.91)\end{array}$ & $\begin{array}{c}-0.24 \\
(-3.65)\end{array}$ & $\begin{array}{c}0.09 \\
(0.32)\end{array}$ \\
\hline
\end{tabular}




\begin{tabular}{|c|c|c|c|c|c|c|c|c|c|c|}
\hline \multicolumn{11}{|c|}{ Panel B: Variance Equation } \\
\hline & US-UK & US-CN & US-BD & US-JP & US-IR & US-GR & US-PO & US-HK & US-SG & US-MY \\
\hline \multirow{2}{*}{$C_{U S, U S}$} & 0.002 & 0.002 & 0.002 & 0.002 & 0.001 & 0.003 & 0.0003 & 0.004 & 0.002 & 0.002 \\
\hline & (1.16) & $(0.97)$ & (1.98) & $(0.72)$ & $(0.18)$ & (2.68) & (0.19) & (1.47) & (3.02) & (1.29) \\
\hline \multirow{2}{*}{$C_{U S, i}$} & 0.001 & 0.002 & 0.003 & 0.004 & 0.002 & 0.002 & 0.003 & -0.0006 & 0.003 & 0.002 \\
\hline & (1.58) & (2.49) & (2.50) & (2.57) & (1.28) & (1.92) & $(0.92)$ & $(-0.29)$ & (5.03) & (2.07) \\
\hline \multirow{2}{*}{$c_{i, i}$} & 0.003 & 0.0006 & 0.006 & 0.01 & 0.01 & 0.003 & 0.006 & 0.005 & 0.004 & 0.001 \\
\hline & (5.39) & $(0.49)$ & (3.88) & (5.71) & (5.38) & (1.89) & (4.15) & (3.65) & (2.88) & $(0.73)$ \\
\hline \multirow{2}{*}{$a_{U S, U S}$} & 0.14 & 0.23 & 0.29 & 0.09 & -0.09 & 0.05 & 0.10 & -0.06 & 0.07 & 0.09 \\
\hline & (2.84) & (3.70) & (6.39) & (2.05) & $(-0.59)$ & (1.18) & (1.40) & $(-0.35)$ & (2.10) & $(1.22)$ \\
\hline \multirow{2}{*}{$a_{U S, i}$} & 0.01 & -0.001 & -0.11 & -0.19 & 0.16 & 0.03 & -0.02 & 0.01 & -0.004 & 0.03 \\
\hline & (0.30) & $(-0.03)$ & $(-1.30)$ & $(-5.73)$ & (4.21) & (0.87) & $(-0.71)$ & $(0.11)$ & $(-0.14)$ & (1.46) \\
\hline \multirow{2}{*}{$a_{i, i}$} & 0.04 & 0.29 & 0.27 & -0.03 & -0.01 & 0.19 & 0.24 & 0.34 & 0.20 & 0.23 \\
\hline & $(0.66)$ & (7.47) & $(4.05)$ & $(-0.62)$ & $(-0.04)$ & (4.34) & (7.79) & (5.03) & (5.88) & (5.53) \\
\hline \multirow{2}{*}{$\beta_{U S, U S}$} & 0.96 & 0.93 & 0.92 & 0.94 & 0.94 & 0.95 & 0.95 & 0.87 & 0.95 & 0.95 \\
\hline & (49.84) & (35.66) & (29.05) & (35.99) & (28.67) & (34.96) & (17.75) & (19.18) & (58.15) & (27.31) \\
\hline \multirow{2}{*}{$\beta_{U S, i}$} & -0.01 & 0.007 & -0.003 & -0.02 & 0.001 & -0.02 & -0.01 & 0.05 & -0.04 & -0.01 \\
\hline & $(-0.42)$ & $(0.55)$ & $(-0.12)$ & $(-0.99)$ & $(0.04)$ & $(-1.38)$ & $(-0.54)$ & (1.71) & $(-9.13)$ & $(-1.13)$ \\
\hline \multirow{2}{*}{$\beta_{i, i}$} & 0.93 & 0.94 & 0.86 & 0.80 & 0.84 & 0.95 & 0.92 & 0.90 & 0.92 & 0.96 \\
\hline & (64.76) & (80.18) & (16.50) & (11.91) & (19.03) & (41.32) & (33.22) & (28.42) & (39.52) & (86.51) \\
\hline \multirow{2}{*}{$\gamma_{U S, U S}$} & 0.22 & 0.31 & 0.16 & 0.31 & 0.35 & 0.29 & 0.30 & 0.30 & 0.22 & 0.34 \\
\hline & (2.76) & (4.47) & (1.12) & (4.63) & (1.85) & (3.24) & (1.95) & (2.05) & (2.43) & $(2.70)$ \\
\hline \multirow{2}{*}{$\gamma_{U S, i}$} & 0.11 & 0.01 & 0.20 & 0.05 & -0.02 & 0.15 & 0.10 & 0.19 & 0.23 & 0.06 \\
\hline & (1.35) & $(0.25)$ & (2.32) & $(1.50)$ & $(-0.14)$ & (3.64) & (1.68) & (3.40) & (6.00) & (1.78) \\
\hline \multirow{2}{*}{$\gamma_{i, i}$} & 0.34 & 0.12 & 0.40 & 0.38 & 0.55 & 0.18 & 0.27 & -0.09 & 0.24 & 0.06 \\
\hline & (6.79) & (1.91) & (3.60) & (3.71) & (3.33) & $(2.44)$ & (2.47) & $(-0.42)$ & (4.92) & $(0.59)$ \\
\hline
\end{tabular}

Equation (1) is estimated by maximum likelihood with optimization performed using the BFGS algorithm. Robust $\boldsymbol{t}$ - tests are reported in parentheses. Entries that are statistically different from zero at the $10 \%$ confidence level are represented in bold 
crises but not beyond. A priori, we might have expected that the current shock which originated in the financial sector would have led to even greater levels of correlation than recorded during the earlier crisis which stemmed from the technological sector. However, this has not been the case and the levels of co-movement exhibited by the financial sectors of our sampled countries have not been excessive by historical standards.

Table 4: Results of Principal Component Analysis

\begin{tabular}{lcc}
\hline \multirow{2}{*}{ Country Pair } & \multicolumn{2}{c}{ Factor Loadings on First PC } \\
\cline { 2 - 3 } & Financials & Non- Financials \\
\hline US - UK & 0.446 & 0.421 \\
US - Canada & 0.441 & 0.415 \\
US - Germany & 0.428 & 0.424 \\
US - Japan & 0.196 & 0.290 \\
US - Ireland & 0.322 & 0.281 \\
US - Greece & 0.239 & 0.237 \\
US - Poland & 0.246 & 0.264 \\
US - Hong Kong & 0.293 & 0.265 \\
US - Singapore & 0.239 & 0.284 \\
US - Malaysia & 0.145 & 0.177 \\
& & \\
\hline
\end{tabular}

\section{Variability explained}

\section{by First PC}

$0.963 \quad 0.962$

Notes: We perform a principal components analysis on the ten conditional correlations. We report only results for the first factor as it accounts for almost of the variation.

Furthermore, both the level and long-run trend of our conditional correlation measures exhibit a considerable amount of commonality, which suggests that there may be an underlying latent factor driving these co-movements. A principal components analysis of the ten conditional correlations shows that only the first component matters, accounting for approximately 96 percent (98 percent for the filtered series) of the common variation. ${ }^{6}$ Factor loadings on this first component are

\footnotetext{
${ }^{6}$ This finding is similar when we use the entire sample or limit it to 'developed countries'.
} 
presented in Table 4. These are all of the same sign and of roughly similar magnitude. The largest loadings are found for countries that are most integrated with the US (for example, UK and Canada) or had greatest dependence on the financial sector (for example, Ireland). This is a very strong result, and though this principal component does not correlate directly with any observable measure, we find statistical evidence that it is related to both US returns and the spread of three-month LIBOR over the three-month Treasury-bill rate (which serves as a measure of credit and liquidity risk). The role of US returns is due to the fact that the US market is omnipresent in all market pairs analyzed and the leader role of the US market discussed earlier. The role of liquidity in the recent credit crisis seems consistent with the evolution of the current financial turmoil and the arguments of Brunnermeier and Pedersen (2009). We know that the financial system was awash with liquidity over the 2004-06 period but this fell sharply as the current crisis began to grip many countries and, in particular, their financial institutions. As discussed earlier, financial institutions required more liquidity to cover their own positions and also began to hoard liquid assets due to fears of counterparty risk. Brunnermeier (2009) highlights the role of liquidity shortages in the propagation of this crisis. The long-run correlation movements shown here also exhibit a similar pattern to the liquidity risks generated from bond markets in Fontaine and Garcia (2009). It is conceivable that the lack of liquidity in the financial system depressed the activities of all financial companies and consequently, increased the conditional correlation between all pairs considered. The levels of co-movement appear to be positively related to the relative importance of the financial sector in the overall economy and the level of financial integration. Markets that are less integrated or less sophisticated in terms of their financial architecture may have avoided some of the excesses of this current crisis, as for example Malaysia.

\section{Non-financial versus Financial Stocks}

For comparison, we next turn our attention to non-financial stocks. We repeat the analysis to ascertain whether these stocks were similarly affected by recent events or if they can provide a method diversifying the risk of financial stock portfolios. Again, we apply the bivariate GARCH model outlined in equation (1) and the results are presented in Table 3. 
Figure 3: Time-varying Cross-country Conditional Correlations of Nonfinancial Stock Returns
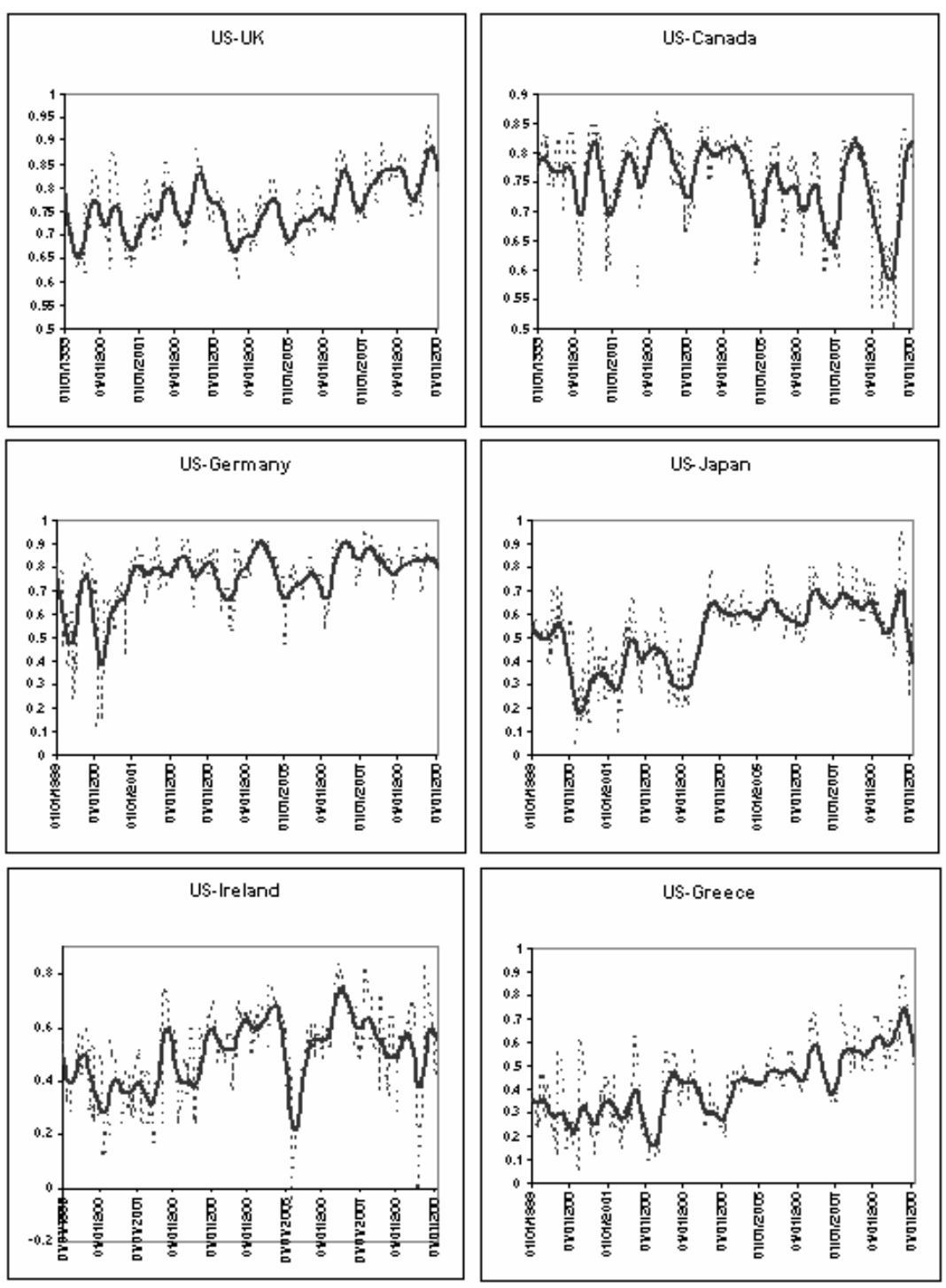

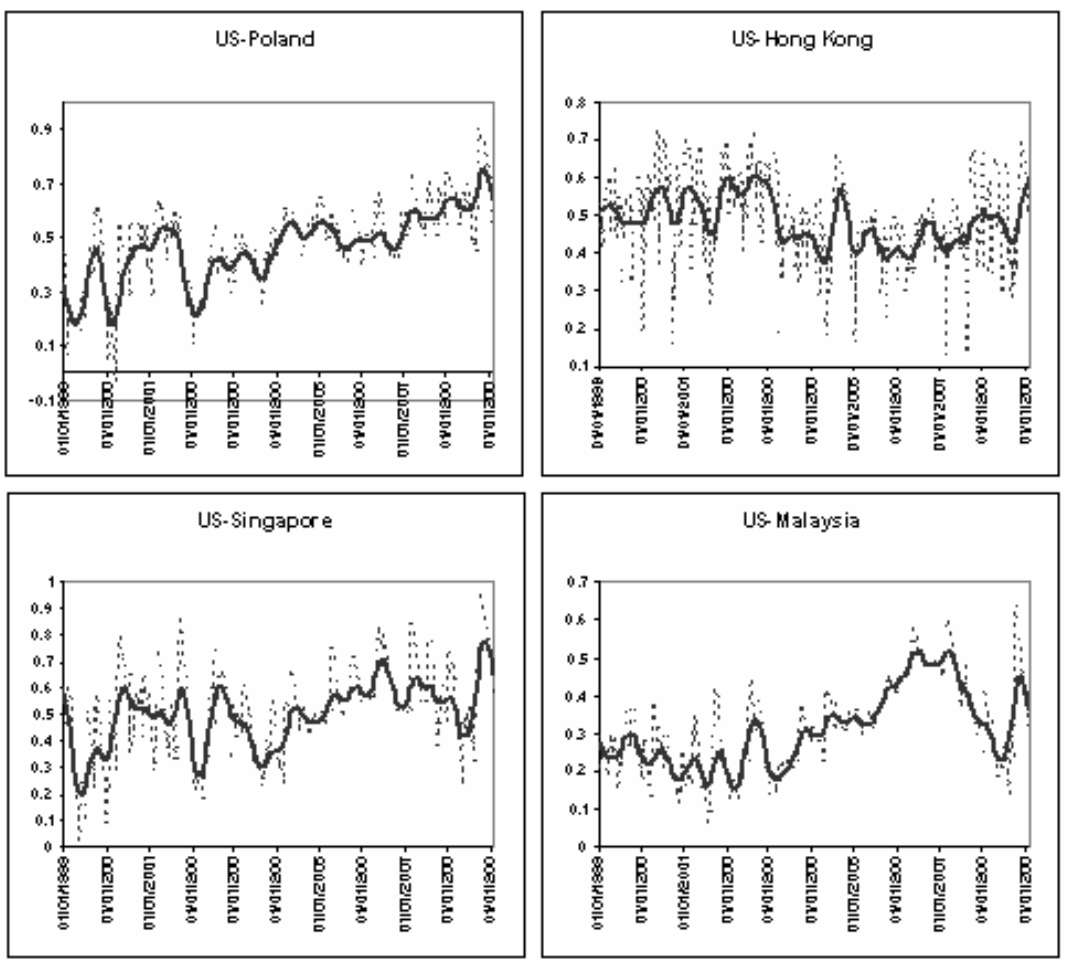

For non-financial stocks, there is very little predictability in the conditional mean (Panel A). There is again evidence that the US acts as a market leader in this sector with its lagged return being a statistically significant predictor of returns in other markets. However, we now find little evidence that adverse shocks have a persistent effect on current returns. Non-financial sector returns are largely serially independent and unpredictable. In common with their financial counterparts, these stocks also exhibit strong evidence of time variation in the conditional second-order moments. Most of the time-variation comes from the persistence parameters (B matrix). However, all country pairs have sufficient statistically significant parameters to justify the adoption of a GARCH $(1,1)$ specification for the conditional secondorder moments of the process. Once more the asymmetric response to bad news is clearly manifest. The conditional volatility of non-financial stocks also reacts more strongly to adverse conditions, leading to increased risk for all stocks in the sector.

Figure 3 presents the time-varying cross-country conditional correlations for the non-financial sector. For most countries, the pattern is comparable to that observed for financial stocks, though in some cases the range of values is dampened. This implies that even if the sector is less integrated than its financial counterpart, the dynamics of their co-movements are similar. Correlations in this sector also increase 
during periods of financial turmoil. However, for a number of markets, (for example, UK, Singapore, Greece and Poland), their current correlations with the US are higher than at any other time during the decade. This suggests that the current financial turmoil has been more distressing for non-financial firms than the earlier crises in this decade. A principal components analysis of the cross-country correlations of the non-financial sector yields results that are very similar to those of the financial sector (see Table 4). Again, the first principal component accounts for almost the entire variation and factor loadings are similar to those in the financial sector. The correspondence of results for non-financial stocks with those of the financial sector may be due to the dependence of these stocks on the overall financial health of the global economy. It also shows the difficulty in creating a hedge against shocks to the financial sector. The important role of the financial sector in facilitating the operation of economic activity means that shocks hitting this sector behave like systematic shocks. Due to the pervasive nature of the 'credit crunch', it appears that much of the risk inherent in financial stocks was indeed systematic and could not be diversified away by holding stocks from other sectors. Many non-financial companies were faced with increased costs of borrowing due to the scarcity of money and the reluctance of the banking sector to issue risky loans. In fact, the upward trend in correlations is greater for the non-financial sector at the end of our sample as the real economy began to feel the effects of the crisis and many countries experienced recession.

We extend the analysis to examine the co-movements of 'financial and nonfinancial' stocks within each country and the financial stocks of one country with the non-financials of another country. In all cases, we find similar patterns. ${ }^{7}$ This further supports the hypothesis that this shock was largely systematic, and strategies based upon either geographical or industrial diversification were unlikely to deliver much benefit in terms of risk reduction.

\section{Conclusions}

We analyze the risks and co-movements of stock returns over the past decade, paying particular attention to their behaviour around the time of the recent and on-going credit crunch. We break the market into two broadly defined sectors, namely financial and non-financial stocks. Despite the origins of the shock, we find that the stocks of both sectors behave remarkably alike. For both sectors, stock returns exhibit little autocorrelation, but we find strong evidence of time-variation in their conditional second-order moments. Furthermore, both the levels and particularly the volatility process of returns display evidence of heightened sensitivity to bad news events. Cross-country correlations are examined for all pairs containing the United States as the base market. They exhibit significant time variation and increase during periods of financial turmoil. However, correlations between financial indices do not

${ }^{7}$ For brevity, these results are not reported but are available from the authors upon request. 
exceed previous highs during the current crisis. Current levels of co-movement return correlations to the levels recorded in 2001-02 around the collapse of the dot.com bubble and the LTCM hedge fund but not beyond.

Our generated conditional correlations for the financial sectors exhibit similar patterns of co-movement, so strong that a principal components analysis reveals that the first component accounts for about 96 percent of the variation. We find a weak but statistically significant relationship between this factor and both US returns and an interest rate spread (LIBOR - T-bill rate). This is consistent with the leadership role of the US in the financial system and the importance of liquidity risk in propagating the current crisis across markets. The behaviour of non-financial stocks is largely similar. We find no evidence that this sector can offer a good hedge against financial shocks. In fact, it suggests that the shocks in financial markets that caused the initial crash became systematic and pervasive factors affecting all equities regardless of sector. The central role of the financial sector implies that its health is crucial to the whole economy; such is its role in facilitating economic activity. Any shocks that it suffers are likely to be transmitted throughout other sectors through credit and liquidity channels. Therefore, ensuring that financial markets are properly regulated is of paramount importance for the future prosperity of the global economy.

\section{References}

Bollerslev, T., (1986), "Generalized Autoregressive Conditional Heteroskedasticity", Journal of Econometrics, 31, 307-327.

Bordo, M.D. and Murshid, A.P., (2000), “Are Financial Crises Becoming Increasingly More Contagious? What Is the Historical Evidence on Contagion?", National Bureau of Economic Research paper no. 7900.

Brunnermeier, M.K., (2009), "Deciphering the 2007-08 Liquidity and Credit Crunch", Journal of Economic Perspectives, 23 (1), 77-100.

Brunnermeier, M.K. and Pedersen, L., (2009), "Market Liquidity and Funding Liquidity", Review of Financial Studies, 22 (6), 2201-2238.

Campbell, J.Y., Lettau, M., Malkiel, B.G. and Xu, Y., (2001), "Have Individual Stocks Become More Volatile? An Empirical Exploration of Idiosyncratic Risk", Journal of Finance, 56 (1), 1-43.

Cappiello, L., Engle, R. and Sheppard, K., (2006), "Asymmetric Dynamics in the Correlations of Global Equity and Bond Returns", Journal of Financial Econometrics, 4 (4), 537-572.

Engle, R.F., (1982), "Autoregressive Conditional Heteroskedasticity with Estimates of the Variance of United Kingdom Inflation", Econometrica, 50, 987-1007.

Engle, R.F. and Ng, V., (1993), "Measuring and Testing the Impact of News on Volatility", Journal of Finance, 48 (5), 1749-1778.

Fontaine, J.S. and Garcia, R., (2009), "Bond Liquidity Premia", Mimeo, EDHEC Business School. Available at SSRN: http://ssrn.com/abstract=966227 
Forbes, K.J. and Rigobon, R.J., (2002), "No Contagion, Only Interdependence: Measuring Stock Market Comovements", Journal of Finance, 57 (5), 2223-61.

Glosten, L.R., Jagannathan, R. and Runkle, D.E., (1993), "On the Relation between the Expected Value and the Volatility of the Nominal Excess Return on Stocks", Journal of Finance, 48 (5), 1779-801.

Longin, F. and Solnik, B., (2001), "Extreme Correlation in International Equity Markets", Journal of Finance, 56 (2), 649-676.

Schwert, G. W., (1989), "Why Does Stock Market Volatility Change Over Time?", Journal of Finance, 44 (5), 1115-1153 . 
